\title{
Nadir görülen habis kemik tümörlerine yaklaşım: Adamantinoma ve kordomanın tanı ve tedavi özellikleri
}

\author{
Management of rare, malignant bone tumors: \\ Diagnosis and treatment of adamantinoma and chordoma
}

\author{
Harzem Özger ${ }^{1}$, Buğra Alpan² \\ ${ }^{1}$ İstanbul Üniversitesi, İstanbul Tıp Fakültesi, Ortopedi ve Travmatoloji Anabilim Dalı, Çapa-Fatih, İstanbul \\ ${ }^{2}$ Acıbadem Maslak Hastanesi, Ortopedi ve Travmatoloji Bölümü, İstanbul
}

\begin{abstract}
Adamantinoma ve kordoma, her ikisinin de nadir görülen, düşük dereceli habis kemik tümörleri olması nedeniyle, literatürde sıklıkla birlikte ele alınır. Temel ortak özellikleri, hastaların adjuvan tedavi modalitelerinden yarar görmemeleri ve geniş rezeksiyonun kür sağlayabilecek tek tedavi seçeneği olmasıdır. Lokal nüks potansiyelleri yüksektir.
\end{abstract}

Uzun kemiklerde, sıklıkla da tibia diyafizinde görülen bifazik bir tümor olan adamantinoma, selim bir kemik patolojisi olan osteofibröz displazi ile karıştırılmamalıdır. Tedavisi, geniş rezeksiyon ve tercihen biyolojik yöntemlerle interkaler defekt rekonstrüksiyonu şeklinde özetlenebilir.

Kordoma, vertebral kolonun herhangi bir noktasındaki notokord atıklarından köken alır. Ortopedik onkoloji ile uğraşan hekimler genel olarak sakrokoksigeal bölge kordomalarını tedavi ederler. Bu hastalarda, yaşam kalitesini korumak için yapılacak yetersiz rezeksiyonlar, hızla lokal nükse yol açar. Nüks kitleler ise daha morbid rezeksiyonlara yol açar veya inoperabl hale gelirler. Kordomanın cerrahi tedavisi multidisipliner bir yaklaşım gerektirir. Uzak metastazlar, hastalığın çok geç döneminde çıktığı için lokal kontrolün sağlanamadığı hastalar, çok sıkıntılı bir terminal dönem geçirerek hayatlarını kaybederler.

Anahtar sözcükler: adamantinoma; kordoma; düşük dereceli habis; kemik tümörleri; lokal tümör rekürrensi; geniş rezeksiyon; rekonstrüksiyon; yaşam kalitesi; komplikasyonlar

\begin{abstract}
Adamantinoma and chordoma are usually addressed consecutively in the textbooks since both are rare, low-grade malignant bone tumors. Neither of these tumors are sensitive to adjuvant treatment modalities and wide resection is the only curative treatment option for both of them. Both have very high local recurrence risk.
\end{abstract}

Adamantinoma, which is a biphasic tumor with a predilection for tibial diaphysis, must be distinguished from osteofibrous dysplasia, which is a benign condition. Treatment of adamantinoma can be summarized as wide resection followed by intercalary defect reconstruction with preferably biological methods.

Chordoma originates from notochordal remnants in the vertebral column. Orthopaedic oncologists usually treat chordomas of the sacrococcygeal region. Inadequate resections, performed inadvertently or performed with the intent of preserving some function, usually result in early local recurrence. Furthermore, recurring lesions either necessitate more morbid resections or become unresectable. Surgical treatment of chordoma requires multidisciplinary approach. Since distant metastases only appear late in the disease process, patients for whom local control cannot be provided usually experience an agonizing terminal illness period.

Key words: adamantinoma; chordoma; low-grade malignant; bone neoplasms; local neoplasm recurrence; wide resection; reconstruction; quality of life; complications

\section{ADAMANTINOMA}

\section{Genel bilgiler}

Bifazik histolojik paterne sahip, düşük dereceli, ender rastlanan habis bir kemik tümörüdür. ${ }^{[1]}$ Adını benzer bir dokudan köken alan mandibula tümöründen alır. Uzun kemiklerdeki lezyonlar, mandibula tümörlerinden farklı olarak metastaz yapabilirler. Her iki cinste, özellikle 20-50 yaş arasında sık görülür. Lezyonların \%90'ı tibiadadır. Aynı tibiada multifokal lezyonlar olabileceği gibi, \%10 olguda ipsilateral fibulada da lezyon izlenebilmektedir. ${ }^{[1]}$ Humerus, ulna, femur ve diğer kemiklerde görüldüğü de bildirilmiştir. Adamantinoma, primer kemik tümörlerinin yaklaşık binde 4'ünü oluşturur. Bazen fibröz displazi ile birlikte olabilir ya da bunu taklit edebilir.

- İletişim adresi: Prof. Dr. Harzem Özger, İstanbul Üniversitesi, İstanbul Tıp Fakültesi, Ortopedi ve Travmatoloji Anabilim Dalı, Çapa-Fatih, İstanbul Tel: 0532 - 3518199 e-posta: harzemo@yahoo.com

- Gelis tarihi: 17 Haziran 2014 Kabul tarihi: 17 Haziran 2014 


\section{Klinik prezentasyon}

Hastalar, hekime yıllardır devam eden hafif bir ağrı ve yavaş yavaş belirgin hale gelen sert bir şişlik şikayeti ile başvurular. Bazen başvuru şikayeti, patolojik kırık olabilir.

\section{Radyoloji}

Radyografide sklerotik sınırlı, multiloküler, radyolusent bir lezyon olarak görülür. Bu görünüm "sabun- köpüğü"olarak da adlandırılır. ${ }^{[2]}$ Korteks tutulumu, olguların \%80'inde 5cm'den uzun bir segment boyunca görülür. Periost reaksiyonu görülebilir. Radyografik görünüm karakteristik olmakla beraber, manyetik rezonans (MR) ile multisentrik lezyonların varlığı, lezyonun tam uzanımı ve varsa yumuşak doku komponenti görüntülenebilir (Şekil 1. a-d). ${ }^{[1]}$ Akciğer metastaz taraması için bilgisayarlı tomografi (BT) incelemesi uygundur.
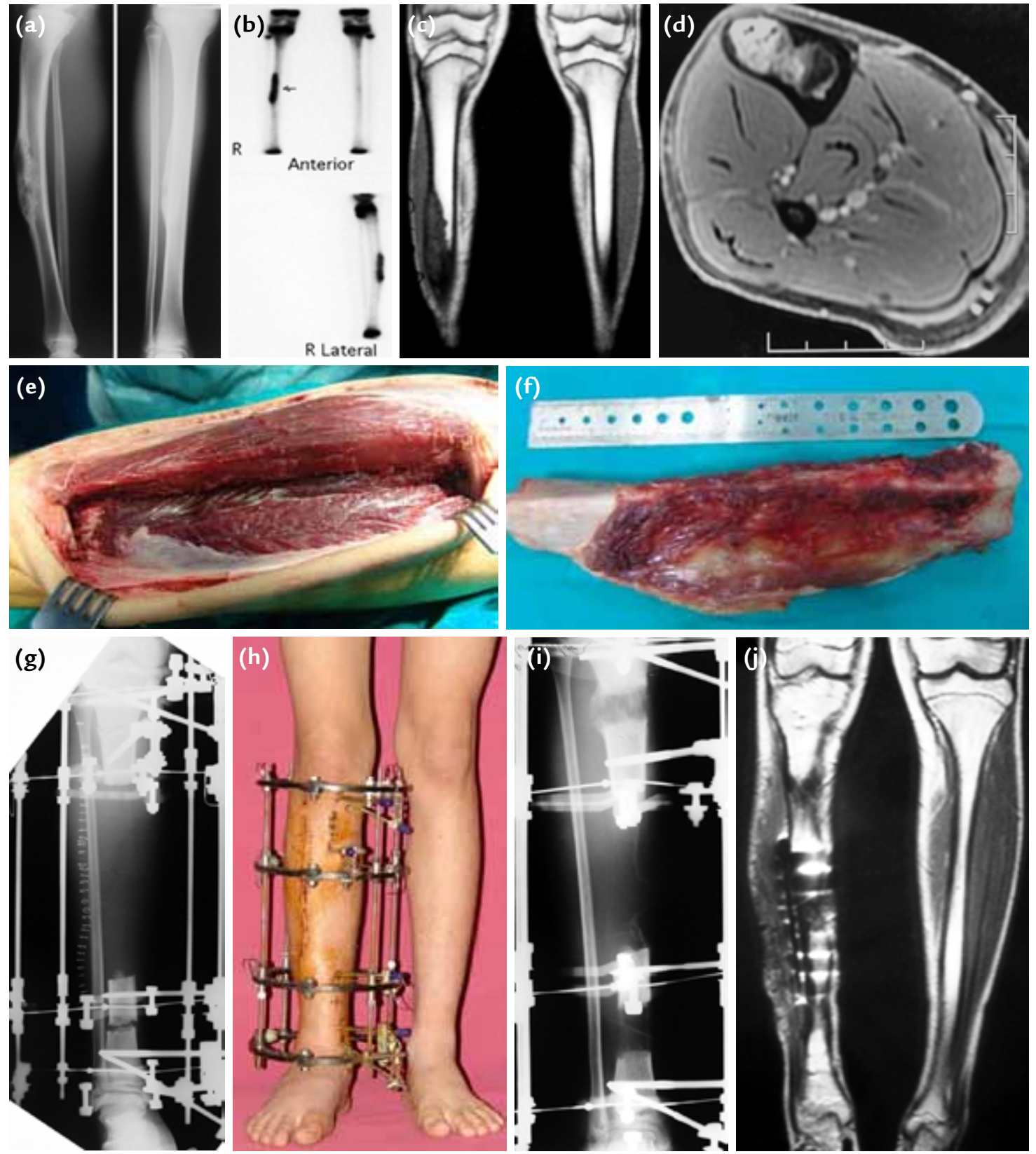

Şekil 1. a-j. On üç yaşında erkek hasta. Tibia üzerinde şişlik nedeniyle başvuran hastanın açık biyopsi sonucu adamantinoma olarak geldi (a-d). Interkaler geniş rezeksiyon uygulandı (e, f). ilizarov eksternal fiksatörü ile bifokal segment kaydırma uygulandı (g-i). Fiksatör çıkarıldıktan sonra iliak kanattan otogrefonaj ve plak-vida ile osteosentez yapılan hastanın 18. ayda kontrol MR görüntüsü (j). 


\section{Histopatoloji}

Klasik adamantinoma, değişik oranlarda ve değişik diferensiyasyon evrelerinde, birbirine karışmış paternde epitelyal ve osteofibröz komponentler içerir. ${ }^{[1]}$

Adamantinoma, sıklıkla dört histolojik alt-tipte incelenir: bazaloid, tübüler, iğsi ve skuamoz. Tüm diferensiyasyon tipleri aynı lezyon içerisinde bulunabilir. Nüks ve metastatik lezyonlarda sıklıkla iğsi-hücreli tipe rastlanır. Osteofibröz komponent içinde, storifom paternde iğsi hücreler mevcuttur. Örülmüş kemik trabeküllerinin üzerinde osteoblastlar dizilidir (Şekil 2).

Mitoz oranı düşüktür. Osteofibröz displazi-benzeri adamantinoma olarak adlandırılan beşinci bir histolojik alt-tip de bulunmaktadır. İmmünhistokimya incelemesinde vimentin, keratin ve EMA pozitif boyanır. Moleküler-genetik çalışmalar, adamantinoma ile pek çok kromozomal anomali arasında ilişki ortaya koymuştur. ${ }^{[1]}$

\section{Tedavi}

Biyopsi ile tanı koyulduktan sonra, kemoterapi ve radyoterapi duyarlılığı olmadığı için tedavi seçeneği olarak geniş sınırlar ile cerrahi rezeksiyon uygulanır. Yeterince geniş sınırlara ulaşıımadığı takdirde çok uzun yıllar sonra dahi lokal nüks ve metastazlar görülebilmektedir. Bu nedenle hastaların cerrahi tedavi sonrasında ömür boyu takip edilmeleri uygundur. ${ }^{[3]}$ Qureshi ve arkadaşlarının yaptığı çalışmada, uzuv kurtarma oranı $\% 84$ ve 10 -yıllık sağkalım oranı $\% 87,2$ olarak bildirilmiştir. ${ }^{4]}$
Uzun kemiklerin diyafizini tutması nedeniyle genellikle interkaler rezeksiyon uygulanır. İnterkaler defektin köprülenmesi, biyolojik veya non-biyolojik rekonstrüksiyon $^{[5]}$ yöntemleri ile yapılabilir, ancak tercih edilmesi gereken yöntem biyolojik rekonstrüksiyondur. Adamantinoma tedavisinde radyoterapi ve kemoterapinin yerinin olmaması, rekonstrüktif cerrahi girişimler açısından bir avantaj yaratır, çünkü artmış enfeksiyon riski, yara iyileşmesi ve kemik kaynaması ile ilgili ek sorunlar ekarte edilir (Şekil 1. e-j).

Rekonstrüksiyona bağlı komplikasyon oranları yüksek olarak rapor edilmektedir ${ }^{[4,6]}$ ancak biz bunun uygulanan rekonstrüktif yöntemlerin eksikliklerine bağlı olduğu kanısındayız. Özellikle uzun segmentlerde tek başına masif allogreft kullanımının biyolojik olarak yetersiz olduğunu ve bu nedenle uzun kemik interkaler defekt rekonstrüksiyonunda serbest damarlı fibula grefti ile kombine edilmiş masif greft kullanılması gerektiğini düşünüyoruz. Uzun kilitli plaklar, bu tür rekonstrüksiyonlarda en stabil osteosentezi sağlar. Adamantinoma olgularında, eksternal fiksatör yardımlı kemik transportu da son derece etkili bir biyolojik rekonstrüksiyon yöntemi olarak kullanılabilir.

\section{Tartışma}

Geniş cerrahi sınırlara ulaşılmadığı takdirde \%90'a varan lokal nüks oranları bildirilmiştir. Lezyonun başvuruda kompartman dışına çıkmış olması da lokal nüks riskini arttıran bir etmendir. ${ }^{[1]}$

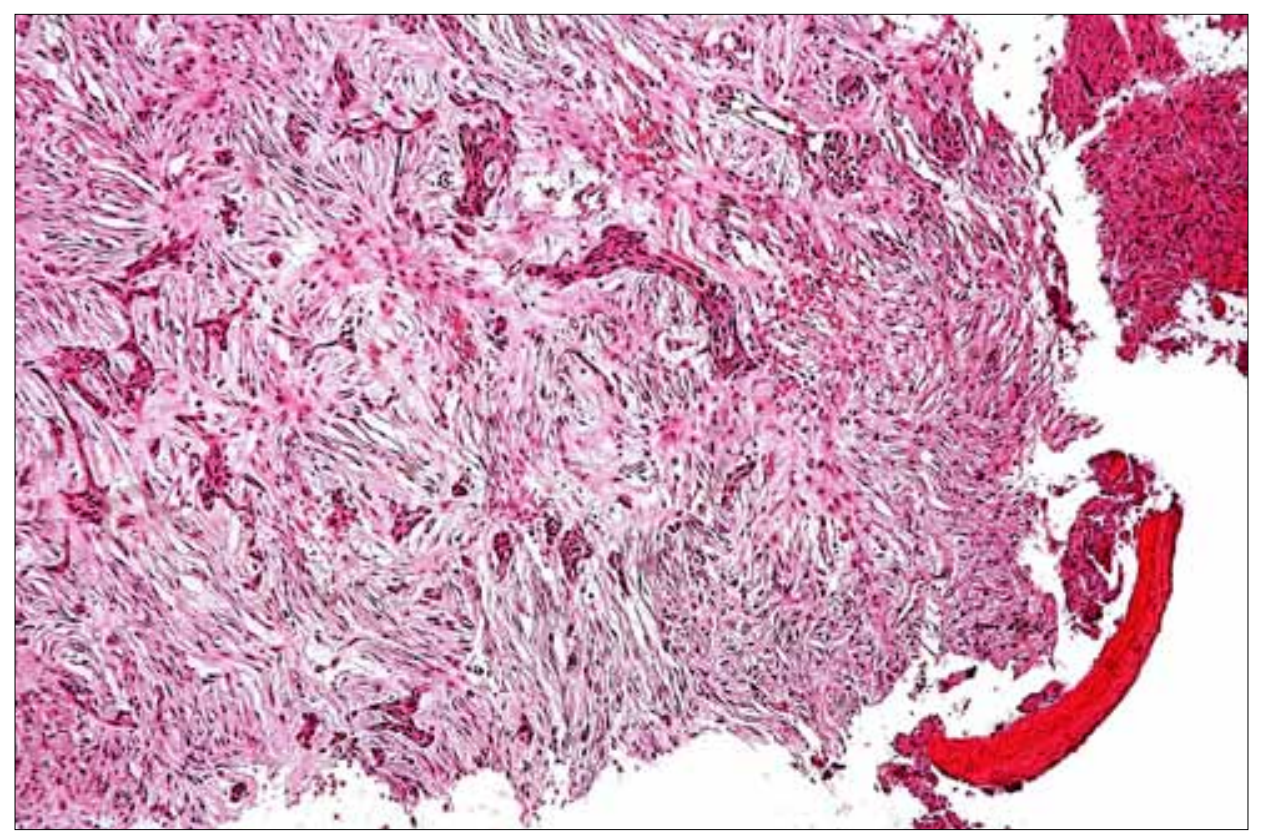

Şekil 2. Adamantinomanın histolojik görünümü. 
Ayırıcı tanı güçlüğü bazen klinisyeni ve patoloğu zor durumda bırakmaktadır. Osteofibröz displazi (OFD), osteofibröz displazi benzeri adamantinoma (OFD-BA) ve klasik adamantinomanın aynı hastalık sprektrumu üzerinde değişik noktalarda bulunan patolojik antiteler olduğu düşünülmektedir ancak bunların birbirine dönüşüp dönüşmediği henüz netlik kazanmamıştır. [7] OFD ve OFD-BA sıklıkla iskelet matüritesine ulaşmamış hastalarda görülürken, adamantinoma genellikle iskelet matüritesinden sonra ortaya çıkar. ${ }^{[8]}$ Adamantinoma genellikle hem korteksi hem de medüller kavitenin tamamını tutarken, OFD ve OFD-BA genellikle medüller kavitenin yalnızca bir kısmını tutar. Küçük lezyonların adamantinomadan ziyade OFD ve OFD-BA olma ihtimali daha yüksektir. ${ }^{[8]}$

\section{KORDOMA}

\section{Genel bilgiler}

Kordoma, sıklıkla kafa tabanı, sakrokoksigeal bölge ve omurganın diğer hareketli segmentlerinde ortaya çıkan, düşük dereceli habis bir orta hat kemik tümörüdür. Lokal agresiftir ve lokal nüks oranı yüksektir. Buna karşın metastaz riski düşüktür. Embriyonik hayatın ikinci ayında kaybolması gereken notokordun kaybolmayan artıklarından köken alır. Bununla beraber, normalde notokord artıkları içeren nükleus pulposustan ise asla köken almaz..$^{[9]}$ Olguların büyük çoğunluğu sporadik olarak ortaya çıkar. Bazı olguların selim notokord hücreli tümörden dönüşüm göstererek ortaya çıktığı da düşünülmektedir. Çok nadir olgularda ailesel geçiş ve tüberöz skleroz kompleksi ile ilişki gösterilmiştir. ${ }^{[10]}$ Genellikle 40-70 yaşları arasında ve erkeklerde daha sık olarak görülür. İnsidansı, yaklaşı olarak milyonda birdir. ${ }^{[10]}$

\section{Klinik prezentasyon}

Kafa tabanında ve oksipitoservikal bileşkede ortaya çıkan kordoma olgularında temel başvuru şikayetleri, baş ağrısı, boyun ağrısı, çift görme veya yüz felcidir. Öte yandan sakrokoksigeal bölge yerleşimli kordoma olgularında sıklıkla bel ağrısı, sakrum bölgesinde baskı hissi, koksidini, kuyruk sokumunda ele gelen kitle, defekasyon güçlüğü, idrar kaçırma veya yapamama, gluteal bölgelere ve bacaklara yayılan ağrı, alt ekstremitelerde kuvvet ve his kaybı, ana başvuru şikayetlerini oluşturmaktadır. ${ }^{[10]}$ Yumuşak doku komponenti posteriora doğru büyüyen kitleler, hastalar tarafindan daha rahat fark edilebilir. Ancak anteriora, yani pelvisin içine doğru büyüyen kitleler, yavaş yavaş ve ağrısız büyüdükleri için uzun süre semptom vermeyebilir. Dolayısıyla, hasta doktora başvurduğunda genellikle kitle büyük boyutlara ulaşmış olur. Dışarıdan palpe edilebilen bir kitle olmasa dahi rektal muayenede kitle ele gelebilir.
Anal sfinkter tonusu ve perine duyusu kontrol edilmeli, her iki alt ekstremitenin özellikle siyatik sinir motor ve duyusal fonksiyonları titizlikle muayene edilmelidir. Cinsel fonksiyon bozukluğu mutlaka sorgulanmalıdır.

\section{Radyoloji}

Sakrokoksigeal kordoma, düz grafide kolaylıkla gözden kaçabilir. Ancak, lezyon kemikte belirgin harabiyete yol açmış ise radyografilerde orta hat yerleşimli, belirsiz sınırlı, litik bir kitle dikkati çekebilir. BT, özellikle kemik yapılardaki yıkımın ortaya konması açısından en hassas görüntüleme modalitesidir. Tümörün hem kemik hem de yumuşak doku komponentleri ile birlikte tüm uzanımının, intrapelvik organlarla, damarlarla ve lumbosakral sinir kökleriyle ilişkisinin gösterilebilmesi açısından en iyi görüntüleme yöntemi ise intravenöz gadolinum kontrastlı MR incelemedir (Şekil 3. a). Lezyonun, T1-ağırlıklı kesitlerde düşük veya orta seviyede sinyal yoğunluğuna sahip olması, T2-ağırlıklı kesitlerde ise şiddetli hiperintens ve lobüle görünümde olması, kordomayı kuvvetle destekler. ${ }^{[9]}$ Hemoraji ve nekroza bağlı olarak MR'de heterojen görünüm elde edilebilir. Kemik sintigrafisinde genellikle periferik artmış tutulum ve santral kısımlarda normal kemiğe oranla azalmış tutulum izlenir. Radyolojik ayırıcı tanıda, kondrosarkom, metastaz ve plazmasitom ilk akla gelecek patolojilerdir. Osteomiyelit, lenfoma, dev hücreli tümör ve anevrizmal kemik kisti de yaş grubu ve diğer klinik ipuçları ışığında akılda tutulmalıdır. ${ }^{[9]}$ Akciğer metastaz taraması için BT incelemesi uygundur.

\section{Biyopsi ve patoloji}

Histopatolojik tanının netleştirilebilmesi için çoğu zaman tru-cut iğne biyopsisi yeterli olur. Biyopsi, ultrasonografi (US) veya BT eşliğinde yapılabilir. Biyopsinin planlanan insizyon hattı üzerinden yapılması hayati önem taşır. Tüm kas-iskelet sistemi lezyonlarında olduğu gibi kordoma ön tanısıyla biyopsi yapılan lezyonlarda da biyopsi materyalinin bu konuda deneyimli bir patolog tarafından incelenmesi çok önemlidir.

Mikroskopik olarak kordomanın üç alt tipi mevcuttur: klasik, kondroid ve dediferansiye. Klasik kordoma histolojisinde, fetal notokorda benzer şekilde kordonbenzeri dizilim gösteren hücre tabakaları ve müsin içerikli büyük vakuolleri bulunan çok-kenarlı "fizaliforöz" hücreler izlenir. Hücre grupları, fibröz septalarla bölünmüş olabilir. İmmünhistokimyasal incelemelerde sitokeratin, S-100 ve EMA boyamaları pozitif sonuç verir (Şekil 4).

Histolojik ayırıcı tanıda, selim notokord hücreli tümör, dev intraosseöz notokordal hamartom, musinöz 

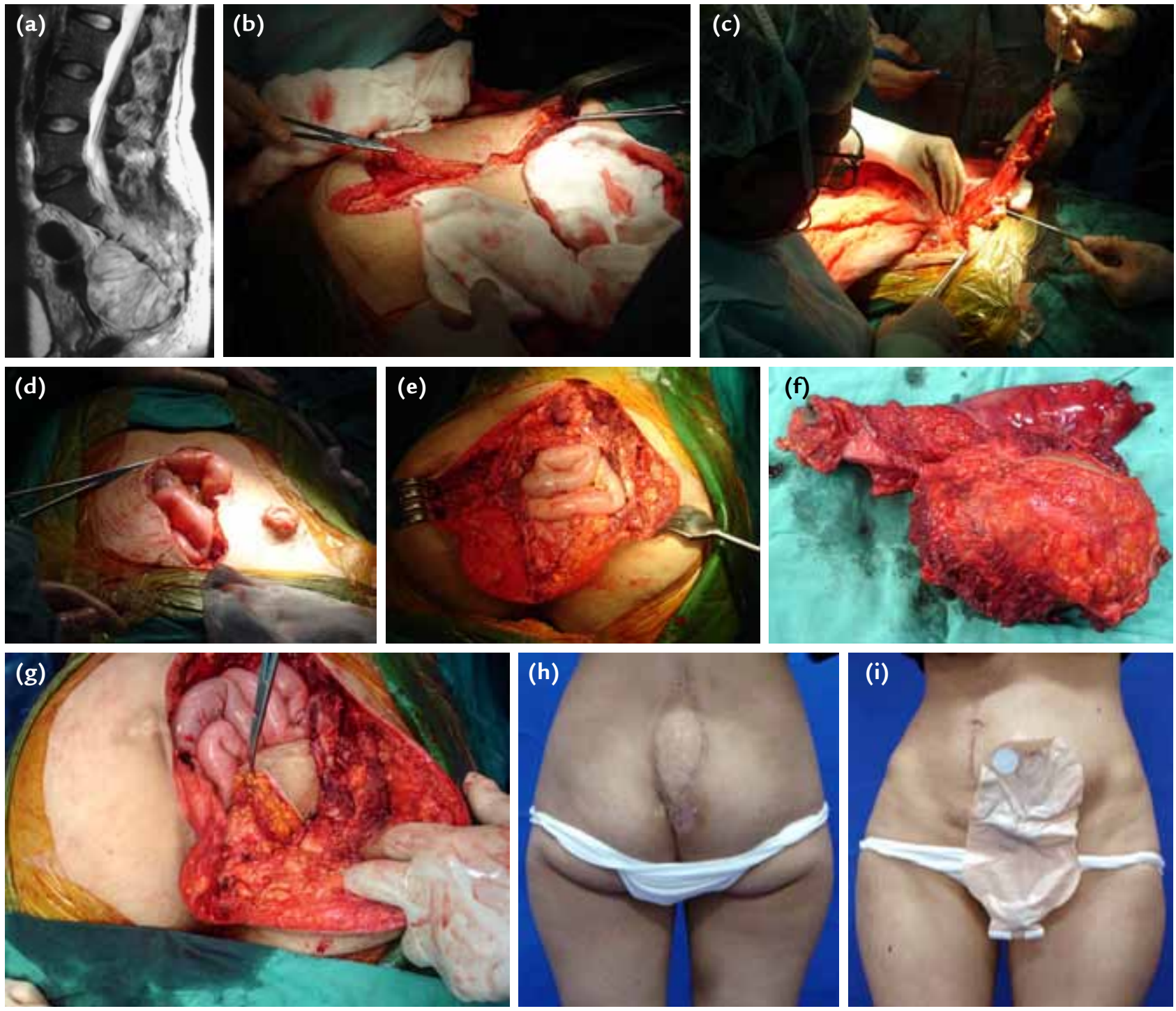

Şekil 3. a-i. Otuz yaşında kadın hasta. Sakral kordoma nedeniyle geniş rezeksiyon planlandı (a). Önce supin pozisyonda hazırlanarak VRAM flebi hazırlandı, batın içine gömüldü $(b, c)$ ve kolostomi açıldı (d). Daha sonra hasta prone pozisyona çevrilerek (e) yapışık olan rektum ile birlikte sakrum en bloc rezeke edildi (f). Rezeksiyon tamamlandıktan sonra ölü boşluğu kapatmak için anteriordan batına gömülen VRAM flebi posteriordan çıkarıldı ve rezeksiyon bölgesine adapte edildi (g). Ameliyat sonrası 8 . ayda sorunsuz iyileşmiş ameliyat bölgesi görülmekte $(h, i)$.

tipi başta olmak üzere rektosigmoid metastatik adenokarsinom, miksoid kondrosarkom ve parakordoma ekarte edilmelidir. ${ }^{[9,10]}$

\section{Tedavi}

Kafatabanı ve oksipitoservikal bölge kordoma olguları, semptomları itibariyle genellikle nöroşirurji uzmanlarına başvururlar. Ortopedik onkoloji uzmanlarının karşısına çıkan olgular ise genellikle sakrokoksigeal bölge tümörleridir. Sakrokoksigeal kordomlardaki tedavi yaklaşımı, felsefi ve teknik açılardan ele alınabilir.
Düşük dereceli habis bir tümör olan kordoma, klasik anlamda radyoterapi ve kemoterapiye duyarsızdır. Buna karşın lokal tekrarlama eğilimi çok yüksektir. Yetersiz cerrahi yapıldığında lokal nüks kaçınılmazdır. ${ }^{[11,12,14,15]}$ Tekrarlayan lokal nükslerin sonucunda tümör cerrahi olarak da ortadan kaldırılamaz boyutlara ulaşır. Kordomanın, düşük dereceli bir habis tümör olması nedeniyle metastazlar, nadiren ve çok ileri aşamalarda meydana çıkar. Metastazlar ortaya çıkana kadar geçen uzun süre içerisinde, nüks etmiş ve inoperabl hale gelmiş kitlelere sekonder olarak defekasyon ve miksiyon kontrolünün kaybı, cinsel işlev 


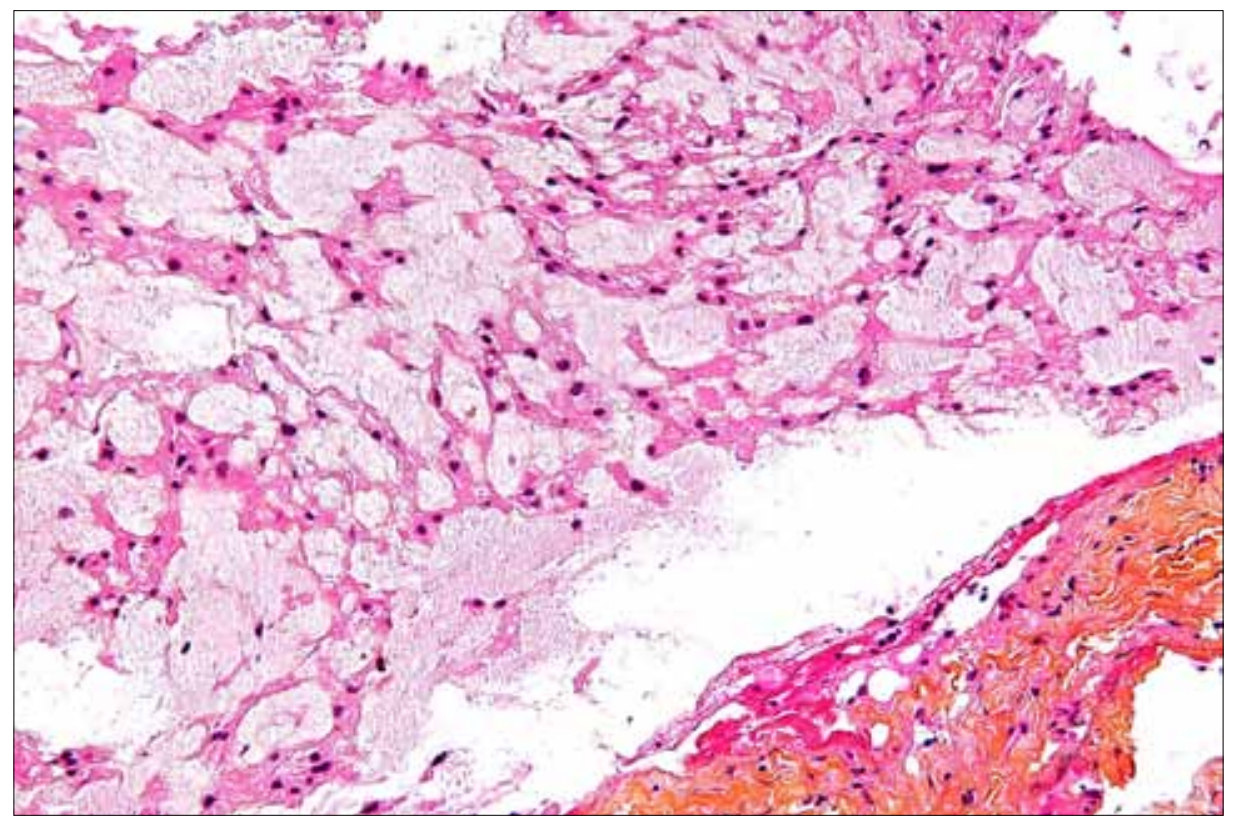

Şekil 4. Kordomanın histolojik görünümü.

bozukluğu ve alt ekstremitelerde duyusal ve motor fonksiyon kayıpları ortaya çıkmaktadır. Ayrıca inoperabl kitleler, büyüyerek zaman zaman eksülsere olmakta, şiddetli ağrı ve sinir felçlerine yol açarak hastanın immobil hale gelmesine ve dekübit yaraları oluşmasına neden olmaktadır. Bu duruma gelen hastalar, ne yazık ki uzun ve sıkıntılı bir terminal dönem yaşamak zorunda kalırlar.

Tek tedavi seçeneği, geniş sınırlarla cerrahi rezeksiyondur ve bu sağlandığı takdirde iyileşme şansı vardır. [11,12,14,15] Öte yandan, sakrokoksigeal bölge tümörlerinde geniş rezeksiyon teknik açıdan çok zordur ve yüksek morbidite-mortalite riski taşır. Bu noktada, cerrahi planlamanın titizlikle yapılması, feda edilecek yapı ve fonksiyonların iyi belirlenmesi, ameliyat sırasında ve sonrası olası komplikasyonlar nedeniyle ortaya çıkabilecek ek kayıpların belirlenmesi ve hastanın ayrıntılı şekilde bilgilendirilmesi, başarılı cerrahi tedavinin ön koşuludur. Hastaların, cerrahi tedavinin, tümörden kurtularak hayatta kalmak için tek şansları olduğunu anlamaları sağlanmalıdır. Cerrahi tedavinin öngörülen sonuçlarından ve olası risklerinden çekinerek cerrahi tedaviyi reddetmenin veya ertelemenin, yalnızca tümörün ilerlemesine, inoperabl hale gelmesine ve korkulan tüm komplikasyonların tümör progresyonu sonucu ortaya çıkmasına yol açacağı, hastaya sabırla anlatılmalıdır. Yaşam kalitesi ve sağkalım ile ilgili beklentiler hastayla açık şekilde paylaşılmalıdır.

Kordomanın cerrahi tedavisi, multidisipliner bir yaklaşım gerektirir. Komplikasyon riskini en aza indirmek için ameliyat öncesi hazırlıklar dikkatle yapılmalıdır. Tümörün spesifik yerleşimine uygun ayrıntılı görüntüleme yapılmış ve özellikle sinir kökleri tanımlanmış olmalıdır. Üreter yaralanması riskine karşı ameliyat öncesi üroloji birimi tarafından double-J kateter yerleştirilmesi, ameliyat sırasında üreterlerin daha kolay palpe edilmesini ve yaralanma olduğu takdirde daha kolay fark edilmesini sağlar. Pulmoner emboli riskini en aza indirmek için seçilmiş olgularda girişimsel radyoloji birimi tarafından vena cava filtresi yerleştirilebilir. Ameliyat sırasında kanama ve hemorajik/hipovolemik şok riskini en aza indirmek için yine girişimsel radyoloji birimi tarafından ameliyat öncesi anjiyoembolizasyon yapılması çok yararlıdır.

Planlanan rezeksiyonun boyutlarına ve planlanan ek cerrahi girişimlere göre anterior-posterior veya yalnızca posterior yaklaşımla cerrahi tedavi uygulanabilir. [13] Rektum duvarına invaze tümörlerde genel cerrahi ekibi tarafından kalıcı kolostomi açılması gerekebilir. Sakrokoksigeal bölgede ameliyat sonrası dönemde yara kontaminasyonu ve yara problemi riskini en aza indirmek için, rektum rezeksiyonu yapılmasa dahi geçici kolostomi açılabilir. Rezeksiyon lojunda oluşan ölü boşluk, ameliyat sonrası dönemde ciddi bir morbidite kaynağıdır. Bu noktada plastik ve rekonstrüktif cerrahiden destek alınabilir. Pelvisin içinden posteriora çevrilen pediküllü rectus abdominis flepleri, ölü boşluk oluşumunun engellenmesi açısından çok büyük önem taşır (Şekil 3. b-i). 
Son derece kompleks ve hayati anatomik ilişkilere sahip sakrokoksigeal bölgede rezeksiyonun güvenli sınırlarla yapılabilmesi, musküloskeletal tümör cerrahının deneyim ve becerisine bağlıdır (Şekil 5. d-f). Rezeksiyon hassasiyetinin arttırılması için, son on yıldır, pelvik tümör cerrahisinde navigasyon sistemlerinin kullanımı ile ilgili çalışmalar yoğunlaşmıştır. ${ }^{[16,17]}$

Total sakrektomi yapılan olgularda lumbopelvik tespit ile mekanik desteğin sağlanması gerekebilir. ${ }^{[18]}$ Lumbopelvik tespit, vertebra enstrümantasyon sistemleri kullanmak suretiyle tamamen non-biyolojik şekilde yapılabileceği gibi, serbest damarlı fibula greftlerinin mikrocerrahi teknikle aktarılması suretiyle biyolojik destekli olarak da yapılabilir.

Ameliyat sonrası dönemde yara problemleri ve derin enfeksiyonlar, debridman ve negatif basınçlı yara kapama sistemleri yardımıyla kontrol altına alınabilir.

Sinir kayıplarını yerine koymak mümkün değildir. Siyatik sinir kayıpları genellikle ayak - ayak bileği ortezleri ile iyi tolere edilir. İdrar kontrolünü kaybeden hastalarda temiz aralıklı kateterizasyon yapılması gerekir. Anal sfinkter kontrolü kaybolan olgularda defekasyonun uzun dönemde belirli bir düzene girdiği gözlenir. Bu olgularda kolostomi iyi bir seçenek olarak gündeme gelir.
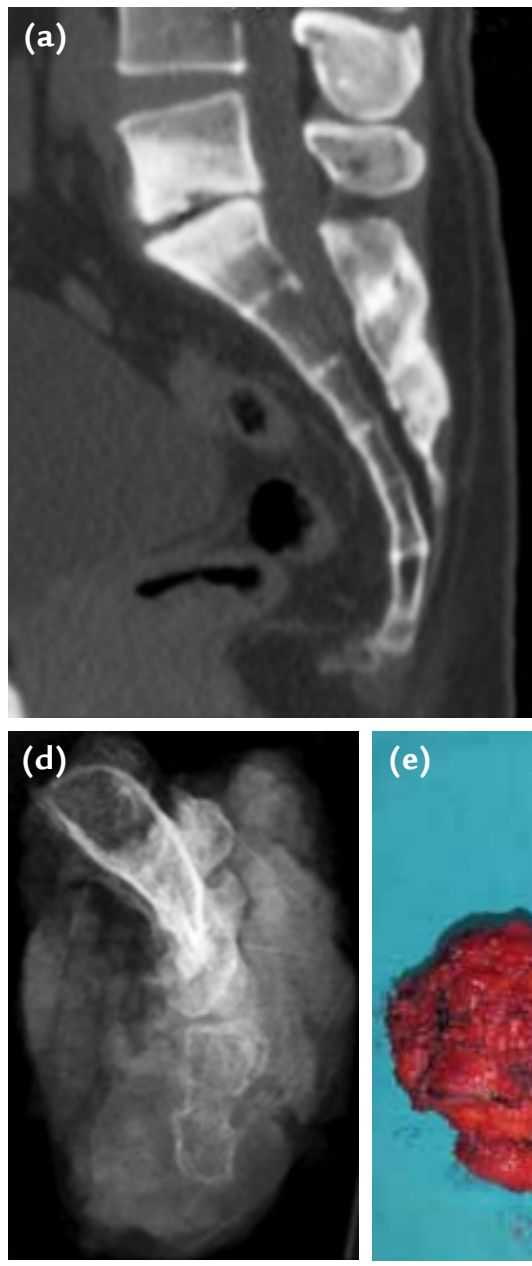
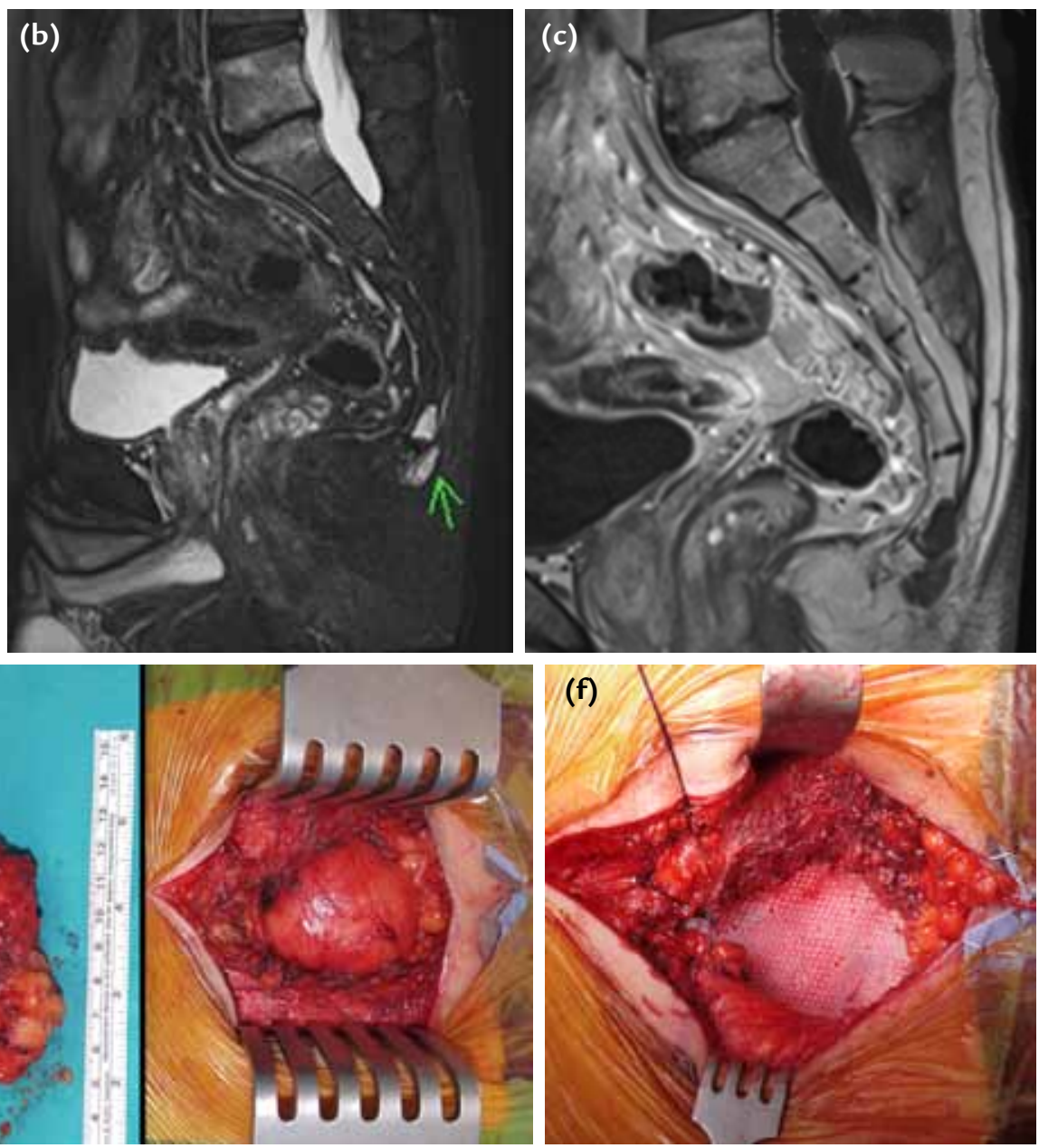

Şekil 5. a-f. Elli yedi yaşında erkek hasta. Lumbosakral dejeneratif spondil artropatiye bağlı bel ağrısı nedeniyle yapılan radyolojik incelemeler sırasında insidental olarak koksiks 3. ve 4. segmentleri tutan kitle tespit edildi. Yaş grubu ve radyolojik özellikler göz önünde tutulduğunda ön planda kordoma düşünüldü. Yerleşim yeri ve kitle boyutları itibariyle iğne biyopsisinden sonuç almanın güç olabileceği ve morbiditeye yol açmaksızın geniş sınırlara ulaşılabileceği öngörülerek eksizyonel biyopsi planlandı (a-c). Koksiks, 1. ve 2. segmentler arasından osteotomize edilerek geniş sınırlarla rezeke edildi (d, e). Sakral kordoma olgularına oranla ölü boşluğun oldukça küçük olması nedeniyle flep rekonstrüksiyonuna ihtiyaç duyulmadı. Rektumun posteriora fıtıklaşmasını engellemek ve koksikse yapışan kas ve bağ dokularının bütünlüğünü sağlamak için çift yüzlü (dual-mesh) sentetik greft ile rekonstrüksiyon yapıldı (f). 
Lokal nüks gelişen olgularda, kabul edilebilir morbidite sınırları içerisinde geniş rezeksiyon ile cerrahi tedavi şansı sonuna kadar kullanılmalıdır. İnoperabl primer veya nüks olgularda ise, yeni nesil radyoterapi modaliteleri[19,20] ve imatinib mesylate gibi hedefe yönelik tedaviler üzerindeki çalışmalar devam etmektedir.

\section{Tartışma}

Kordomalı hastanın tedavisinde ilk girişim prognozu belirleyici olmasına rağmen maalesef çoğunlukla yetersiz, hatta hatalı olmaktadır. Bunun nedenlerini hastaya ve tedavi eden hekime bağı olmak üzere iki grupta incelemek gerekir. Hastaya bağlı nedenler yukarıda anlatılan eksiklikleri hastanın kabul etmemesi nedeniyle cerrahi tedaviden kaçınması, ya da çok gecikerek ve bazen hekimi zorlayarak yetersiz yapılmasına yol açmasıdır.

Hekime bağlı nedenler çok daha önemlidir. Hekime bağlı sorunlar, böyle bir olguyla karşılaşan hekimin:

- durumu doğru değerlendirecek bilgi ve deneyime sahip olmaması,

- hastaya, büyük morbiditeye yol açacak cerrahi yöntemi teklif etmekten ve uygulamaktan kaçınması,

- yeterli cerrahiyi uygulayabilecek deneyim, beceri ve ekibe sahip olmaması,olarak özetlenebilir.

Sakrokoksigeal kordoma hastaları genellikle kabızlık şikayetiyle önce genel cerraha veya bel ağrısı şikayeti ve nörolojik bulgular nedeniyle önce nöroşirurji uzmanına başvururlar (Şekil 5. a-c). Bu nedenle, kordoma olguları, dünyada ve ülkemizde değişik merkezlerde farklı branşlardan hekimler tarafindan tedavi edilir. Bununla beraber biz, kafa tabanı ve oksipitoservikal bölge tümörlerini hariç tutarak, bu olguların ortopedik onkoloji alanında çalışan cerrahlar tarafından tedavi ve takip edilmesinin doğru olduğu kanaatindeyiz. Prognozu belirleyecek en önemli nokta, hastanın tedavi için doğru adrese ulaşmasıdır. Bu hastalar için doğru adres, bu konuda deneyimli bir ortopedik onkoloji uzmanının başkanlığındaki genel cerrah, omurga cerrahı, plastik cerrah ve gereğinde damar cerrahından oluşan bir ekiptir.

\section{KAYNAKLAR}

1. Hogendoorn PCW, Kanamori M. Myogenic, lipogenic and epithelial tumours. WHO Classification of Tumours of Soft Tissue and Bone, 4th ed. Lyon: IARC Press, 2013. p.328-9.

2. Morgan HD. Adamantinoma of the tibia. In: Conrad EU, editor. Orthopaedic Oncology: Diagnosis and Treatment. New York: Thieme Medical Publishers; 2013. p.143-6.
3. Szendroi M, Antal I, Arató G. Adamantinoma of long bones: a long-term follow-up study of 11 cases. Pathol Oncol Res 2008;15(2):209-16. CrossRef

4. Qureshi AA, Shott S, Mallin BA, Gitelis S. Current trends in the management of adamantinoma of long bones. An international study. J Bone Joint Surg Am 2000;82-A(8):1122-31.

5. Mavrogenis AF, Sakellariou VI, Tsibidakis H, Papagelopoulos PJ. Adamantinoma of the tibia treated with a new intramedullary diaphyseal segmental defect implant. J Int Med Res 2009;37(4):1238-45.

6. Bus MP, Dijkstra PD, van de Sande MA, Taminiau $A H$, Schreuder HW, Jutte PC, van der Geest IC, Schaap GR, Bramer JA. Intercalary allograft reconstructions following resection of primary bone tumors: a nationwide multicenter study. J Bone Joint Surg Am 2014;96(4):e26. CrossRef

7. Most MJ, Sim FH, Inwards CY. Osteofibrous dysplasia and adamantinoma. J Am Acad Orthop Surg 2010;18(6):358-66.

8. Bethapudi S, Ritchie DA, MacDuff E, Straiton J. Imaging in osteofibrous dysplasia, osteofibrous dysplasia-like adamantinoma, and classic adamantinoma. Clin Radiol 2014;69(2):200-8. CrossRef

9. Greenspan A, Jundt G, Remagen W. Miscellaneous Tumors and Tumor-like Lesions. Differential Diagnosis in Orthopaedic Oncology, 2nd ed. Philadelphia: Lippincott Williams \& Wilkins; 2007. p.432-45.

10. Flanagan AM, Yamaguchi T. Notochordal tumours. WHO Classification of Tumours of Soft Tissue and Bone, 4th ed. Lyon: IARC Press, 2013. p.328-9.

11. Ozger $H$, Eralp L, Sungur M, Atalar AC. Surgical management of sacral chordoma. Acta Orthop Belg 2010;76(2):243-53.

12. Ruggieri $P$, Angelini A, Ussia G, Montalti M, Mercuri M. Surgical margins and local control in resection of sacral chordomas. Clin Orthop Relat Res 2010;468(11):2939-47. CrossRef

13. Angelini A, Ruggieri P. A new surgical technique (modified Osaka technique) of sacral resection by posterior approach only: description and preliminary results. Spine (Phila Pa 1976) 2013;38(3):E185-92. CrossRef

14. Walcott BP, Nahed BV, Mohyeldin A, Coumans JV, Kahle KT, Ferreira MJ. Chordoma: current concepts, management, and future directions. Lancet Oncol 2012;13(2):e69-76. CrossRef

15. Schwab JH, Springfield DS, Raskin KA, Mankin HJ, Hornicek FJ. What's new in primary malignant musculoskeletal tumors. J Bone Joint Surg Am 2013;95(24):2240-6. CrossRef

16. Cartiaux O, Banse X, Paul L, Francq BG, Aubin CÉ, Docquier $\mathrm{PL}$. Computer-assisted planning and navigation improves cutting accuracy during simulated bone tumor surgery of the pelvis. Comput Aided Surg 2013;18(1-2):19-26. CrossRef

17. Cho HS, Oh JH, Han I, Kim HS. The outcomes of navigationassisted bone tumour surgery: minimum three-year followup. J Bone Joint Surg Br 2012;94(10):1414-20.

18. Varga PP, Lazary A. Chordoma of the sacrum: "en bloc" total sacrectomy and lumbopelvic reconstruction. Eur Spine J 2010;19(6):1039-40. CrossRef

19. Chen YL, Liebsch N, Kobayashi W, Goldberg S, Kirsch D, Calkins G, Childs S, Schwab J, Hornicek F, DeLaney T. Definitive high-dose photon/proton radiotherapy for unresected mobile spine and sacral chordomas. Spine 2013;38(15):E930-6. CrossRef

20. Imai R, Kamada T, Sugahara S, Tsuji H, Tsujii H. Carbon ion radiotherapy for sacral chordoma. Br J Radiol 2011;84 Spec No 1:S48-54. CrossRef 